\title{
Hyperinsulinaemia in non-cirrhotic haemochromatosis: impaired hepatic insulin degradation?
}

\author{
C. Niederau, M. Berger, W.Stremmel, A. Starke, G.Strohmeyer, R. Ebert ${ }^{1}$, E. Siegel ${ }^{1}$ and W. Creutzfeldt ${ }^{1}$ \\ Department of Medicine, University of Düsseldorf, Düsseldorf, and 'Department of Medicine, University of Göttingen, Göttingen, FRG
}

\begin{abstract}
Summary. This study investigated early alterations of glucose metabolism in idiopathic haemochromatosis. Circulating concentrations of glucose, insulin, C-peptide, glucagon, and gastric inhibitory polypeptide (GIP) were measured after a $100-\mathrm{g}$ oral glucose load in 10 men with idiopathic haemochromatosis in the non-cirrhotic stage of the disease. All had normal glucose tolerance and normal body weight. Ten matched healthy subjects were studied as controls. Insulin concentrations increased to significantly higher levels in patients with idiopathic haemochromatosis than in the control subjects from 30 to $180 \mathrm{~min}$ after the glucose load $(p \leqslant 0.01)$, while fasting insulin concentrations were not significantly different ( $p>0.05$ ). Concentrations of glucose, glucagon, C-peptide, and GIP were not significantly different at any time $(p>0.05)$.
\end{abstract}

Thus, patients with idiopathic haemochromatosis show hyperinsulinaemia and hence insulin resistance without impaired glucose tolerance in the non-cirrhotic stage. Since pancreatic insulin secretion (C-peptide), glucagon secretion, and the entero-insulinar axis (GIP) are not impaired in these noncirrhotic patients with idiopathic haemochromatosis, iron accumulation in the hepatocytes may be responsible for the impaired insulin effect and may cause impaired hepatic insulin extraction.

Key words: Hyperinsulinaemia, insulin resistance, insulin degradation, haemochromatosis, cirrhosis, insulin, glucagon; Cpeptide, gastric inhibitory polypeptide.
Diabetes mellitus is one of the classical clinical features in idiopathic haemochromatosis (IHC). The cause of the close association between hyperglycaemia and IHC, however, remains uncertain. Damage to pancreatic islets by iron deposits in $\beta$ cells, genetic predisposition, and hepatic cirrhosis are thought to be the main factors causing diabetes mellitus in IHC [1-4]. Diabetes mellitus and impaired glucose tolerance are also frequent features of other chronic liver diseases [5-6]. Since insulin resistance is a major cause of impaired glucose tolerance in other chronic liver diseases [6-9], it might also be responsible for the impaired glucose tolerance associated with IHC. However, this hypothesis has not been substantiated or refuted so far. This study investigated early alterations of glucose metabolism in IHC: circulating concentrations of glucose, insulin, C-peptide, glucagon, and gastric inhibitory polypeptide (GIP) were measured following an oral glucose load in a homogeneous group of non-cirrhotic IHC patients and were compared with those of matched healthy control subjects.

\section{Subjects and methods}

\section{Subjects}

Ten men with idiopathic haemochromatosis were studied. The clinical data are shown in Tables 1 and 2. The diagnosis was proved in all cases by: (1) histology of liver biopsy; (2) histochemical or chemical determination of iron excess in liver tissue; (3) documentation of abnormal serum concentrations of iron, transferrin, and ferritin; (4) exclusion of other liver diseases, such as that due to alcohol. Most patients had further strong evidence of IHC by determination of HLA antigens and family history (Table 2 ). In seven patients, additional biopsies of the intestinal mucosa were evaluated for iron content. Five of the seven patients had increased iron deposits in the intestinal mucosa (Table 2). IHC patients included in the study had normal glucose tolerance, normal body weight (Broca-index $\pm 10 \%$ ), no history of increased alcohol consumption, and did not show hepatic cirrhosis. All had normal liver function as demonstrated by normal blood coagulation tests and normal serum albumin. Eight of the ten had slightly elevated levels of serum alanine aminotransferase (Table 2). All IHC patients were studied before starting venesection therapy. Ten healthy male subjects were studied as controls. All subjects gave informed consent. The subjects were matched for age, height, weight, and physical activity. The physical data of the IHC patients and the matched healthy controls are shown in Table 1 . Mean values of age, weight, height, and physical activity were almost identical in both groups. 
Table 1. Physical data and maximal insulin concentrations after an oral glucose load in patients with idiopathic haemochromatosis and matched control subjects

\begin{tabular}{|c|c|c|c|c|c|c|c|c|c|c|}
\hline \multirow[t]{2}{*}{ No. } & \multicolumn{5}{|c|}{ Patients with idiopathic haemochromatosis } & \multicolumn{5}{|c|}{ Matched healthy control subjects } \\
\hline & $\begin{array}{l}\text { Age } \\
\text { (years) }\end{array}$ & $\begin{array}{l}\text { Weight } \\
(\mathrm{kg})\end{array}$ & $\begin{array}{l}\text { Height } \\
\text { (cm) }\end{array}$ & $\begin{array}{l}\text { Physical } \\
\text { activity } \\
(1-3)\end{array}$ & $\begin{array}{l}\text { Maximal insulin } \\
\text { concentration } \\
(\mathrm{mU} / \mathrm{l})\end{array}$ & $\begin{array}{l}\text { Maximal insulin } \\
\text { concentration } \\
(\mathrm{mU} / 1)\end{array}$ & $\begin{array}{l}\text { Physical } \\
\text { activity } \\
(1-3)\end{array}$ & $\begin{array}{l}\text { Height } \\
(\mathrm{cm})\end{array}$ & $\begin{array}{l}\text { Weight } \\
(\mathrm{kg})\end{array}$ & $\begin{array}{l}\text { Age } \\
\text { (years) }\end{array}$ \\
\hline 1 & 22 & 74 & 182 & 3 & 60 & 15 & 3 & 188 & 75 & 24 \\
\hline 2 & 23 & 74 & 178 & 1 & 126 & 50 & 1 & 186 & 82 & 21 \\
\hline 3 & 36 & 99 & 192 & 2 & 180 & 78 & 2 & 192 & 95 & 35 \\
\hline 6 & 42 & 86 & 178 & 1 & 64 & 38 & 1 & 186 & 85 & 43 \\
\hline 7 & 48 & 75 & 180 & 1 & 136 & 33 & 2 & 190 & 89 & 45 \\
\hline 8 & 30 & 70 & 175 & 2 & 75 & 58 & 2 & 169 & 68 & 32 \\
\hline 9 & 39 & 66 & 168 & 2 & 90 & 45 & 2 & 176 & 60 & 38 \\
\hline 10 & 38 & 72 & 180 & 2 & 52 & 32 & 2 & 182 & 76 & 39 \\
\hline Mean $\pm S D$ & $37 \pm 9$ & $77 \pm 9$ & $179 \pm 6$ & $1.7 \pm 0.7$ & $95 \pm 42$ & $40 \pm 18$ & $1.7 \pm 0.7$ & $183 \pm 9$ & $79 \pm 11$ & $37 \pm 9$ \\
\hline
\end{tabular}

Physical activity of the subjects at work and in sports was graded as $1=\mathrm{low}, 2=$ normal, and $3=$ high physical activity

Table 2. Clinical data and laboratory investigations in the patients with idiopathic haemochromatosis

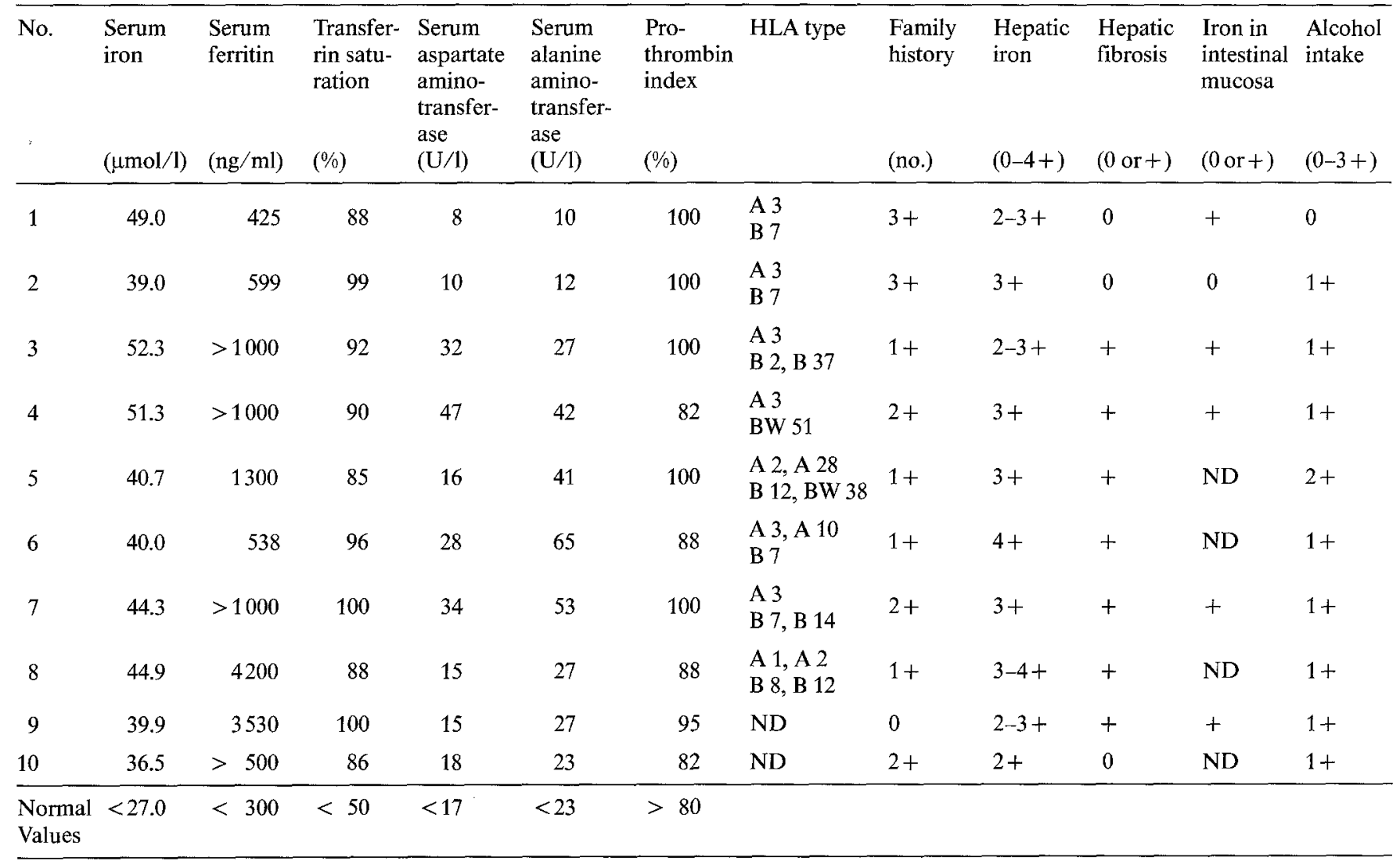

Family history of IHC was graded by the numbers of relatives (parents, grandparents, or siblings) with insulin-dependent diabetes, hepatic cirrhosis, or IHC. Alcohol intake was graded as $0=$ no alcohol, $1=<20 \mathrm{~g} / \mathrm{day}, 2=>20 \mathrm{~g} /$ day, $3=>60 \mathrm{~g} /$ day. Hepatic iron was graded according to [20]. $\mathrm{ND}=$ not determined

\section{Oral glucose tolerance test}

Studies were performed on recumbent subjects after an overnight fast. All had a carbohydrate intake of at least $250 \mathrm{~g} /$ day, abstained from alcohol for $48-72 \mathrm{~h}$ and were not on any drugs. An intravenous Teflon cannula was inserted in an antecubital vein. Glucose $(100 \mathrm{~g})$ was given orally in $400 \mathrm{ml}$ water at time 0 and blood samples were taken at -10 , $0,30,60,90,120$, and $180 \mathrm{~min}$.

\section{Laboratory determinations}

Glucose was measured by the glucose-oxidase method [10]. Concentrations of glucagon and GIP were determined by radioimmunoassay as described previously [11-14]. The intra-assay variance for the radioimmunoassay of GIP was $6.2 \pm 0.9 \%$ and the interassay variance $14.1 \pm 1.2 \%$ (mean \pm SEM of five assays). Commercial kits were used to measure the plasma concentrations of insulin (Pharmacia, Uppsa- 
Table 3. Mean concentrations of glucose, insulin, C-peptide, GIP, and glucagon after $100 \mathrm{~g}$ oral glucose load in the subjects studied

\begin{tabular}{|c|c|c|c|c|c|c|c|c|}
\hline & & \multicolumn{7}{|c|}{ Time after $100 \mathrm{~g}$ glucose load (min) } \\
\hline Glucose (mmol/1) & IHC patients & 4.2 & 3.8 & 7.0 & 7.4 & 6.3 & 5.7 & 4.6 \\
\hline \multirow[t]{2}{*}{ Insulin $(\mathrm{mU} / \mathrm{l})$} & IHC patients & 12 & 12 & $84^{a}$ & $72^{\mathrm{a}}$ & $65^{\mathrm{a}}$ & $62^{\mathrm{a}}$ & $33^{a}$ \\
\hline & Control subjects & 10 & 10 & 34 & 37 & 34 & 32 & 18 \\
\hline \multirow[t]{2}{*}{$\mathrm{GIP}(\mathrm{pg} / \mathrm{l})$} & IHC patients & 90 & 119 & 1017 & 926 & 910 & 1025 & 874 \\
\hline & Control subjects & 250 & 247 & 1141 & 1198 & 981 & 1082 & 933 \\
\hline \multirow[t]{2}{*}{ Glucagon (pg/l) } & IHC patients & 148 & 144 & 142 & 126 & 121 & 121 & 112 \\
\hline & Control subjects & 140 & 141 & 132 & 124 & 119 & 115 & 120 \\
\hline
\end{tabular}

a $p<0.01$ between IHC patients and the matched controls

la, Sweden) and plasma concentrations of C-peptide (Novo, Copenhagen, Denmark).

\section{Statistical methods}

The statistical significance of differences between concentrations of glucose, insulin, C-peptide, glucagon, and GIP in the two groups was calculated using Wilcoxon's test for paired values.

\section{Results}

Concentrations of glucose, insulin, C-peptide, glucagon, and GIP are shown in Table 3. Insulin concentrations increased to significantly higher levels in IHC patients than in the healthy subjects $(p \leqslant 0.01$; Fig. 1$)$. This difference was significant at all times between 30 and $180 \mathrm{~min}$. In all 10 IHC patients, the maximal serum insulin concentration after glucose was higher when compared with the corresponding matched control subjects (Table 1). Fasting insulin concentrations were not significantly different in IHC patients compared with the healthy subjects $(p>0.05)$. Concentrations of glucose, glucagon, GIP, and C-peptide were not significantly different in IHC patients or healthy control subjects at any time $(p>0.05)$.

\section{Discussion}

These results show hyperinsulinaemia after oral glucose in patients with non-cirrhotic IHC compared with healthy control subjects, even though all IHC patients had normal glucose tolerance. The association of hyperinsulinaemia and normal (or impaired) glucose tolerance is often described as insulin resistance [6-7].

Insulin resistance has been thought to occur in $\mathrm{IHC}$ for some time [15], since most other chronic liver diseases also show hyperinsulinaemia and insulin resistance [5-7]. There are only a few rather inconclusive studies on insulin secretion and glucose metabolism in

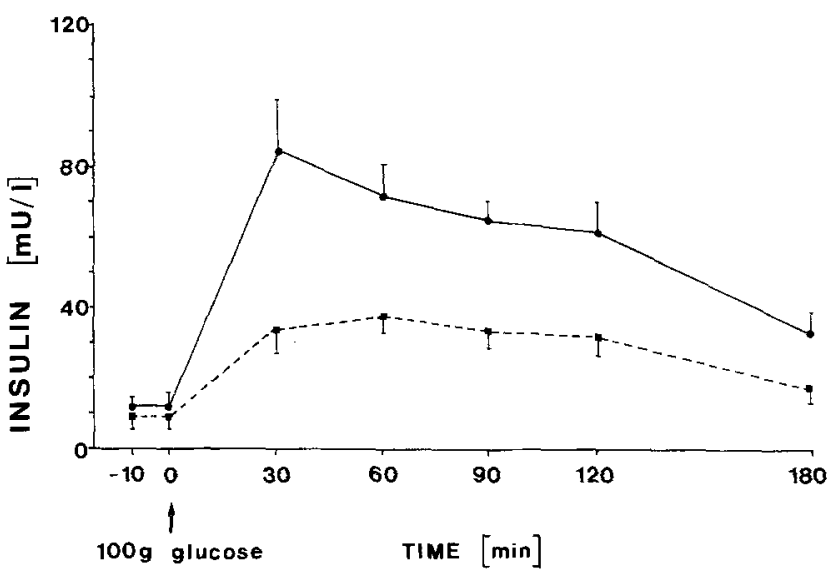

Fig. 1. Insulin concentrations of the 10 IHC patients (- - ) compared with 10 matched healthy control subjects after a $100-\mathrm{g}$ glucose load (--- Each point represents mean \pm SEM

IHC [16-17]. Two showed deficient or delayed insulin responses to oral glucose and failed to prove insulin resistance. In these studies, however, IHC patients were not characterized by liver biopsies or grouped according to their body weight, glucose tolerance or diabetes mellitus [16-17].

As iron overload in IHC may damage pancreatic $\alpha$ and $\beta$ cells, hepatocytes and intestinal mucosa (enteroinsulinar axis), we also measured glucagon, C-peptide, and GIP. Our results show that, in the non-cirrhotic stage of the disease, $\beta$-cell function is not impaired as shown by the normal C-peptide concentrations.

In concordance with a previous study on $\alpha$-cell function in IHC [18], concentrations of glucagon did not differ between IHC patients and healthy subjects. A study in diabetic IHC patients has shown that, in this stage of the disease, glucagon hypersecretion can be observed as in other types of diabetes [19]. Although iron deposits in the intestinal mucosa could be demonstrated in most non-cirrhotic IHC patients, the enteroinsulinar axis is unimpaired as shown by a normal increase of GIP after oral glucose. 
Despite the difference of insulin concentrations between the IHC patients and the control subjects, absolute insulin concentrations were relatively low in both groups due to the fact that all subjects were relatively young men without impaired glucose tolerance and with relatively high levels of physical activity. Obesity, as a cause of hyperinsulinaemia and insulin resistance, was excluded by studying only subjects with normal body weight and by matching the IHC patients and the healthy subjects for body weight. Since $\beta$-cell function, glucagon secretion, and the entero-insulinar axis were demonstrated to be normal, hyperinsulinaemia and the reduced insulin effect (i. e. insulin resistance) may be related to the iron accumulation in hepatocytes. Intrahepatic shunts can be excluded because none of the subjects studied had histological evidence of cirrhosis. A receptor defect or an intracellular impairment of hepatocyte function by iron overload could also produce impaired insulin extraction. As a consequence of this, hyperinsulinaemia is achieved without insulin-hypersecretion as demonstrated by the normal C-peptide levels.

These findings and their interpretation do not rule out the possibility that, as IHC progresses, pancreatic insulin secretion may also become impaired. Indeed, this is to be expected, because of the significantly higher percentage of overt diabetes in IHC patients with cirrhosis compared to patients with cirrhosis from other causes [6]. Following-up the non-cirrhotic IHC patients in the present series may show whether the diabetic tendency of IHC is ameliorated by venesection therapy.

Acknowledgements. The authors were supported by a grant of the Minister für Wissenschaft und Forschung des Landes NordrheinWestfalen and by the Deutsche Forschungsgemeinschaft, Bonn Bad Godesberg, Grant CR 20/17.

\section{References}

1. Dymock JW, Cassar J, Pyke DA, Oakley WG, Williams R (1972) Observations on the pathogenesis, complications and treatment of 115 cases of hemochromatosis. Am J Med 52: 203-210

2. Strohmeyer G, Gottesbueren H, Behr C, Sauer H (1976) Diabetes mellitus bei idiopathischer Haemochromatose. Dtsch Med Wochenschr 101: 1055-1060

3. Saddi R, Feingold J (1974) Idiopathic hemochromatosis and diabetes mellitus. Clin Genet 5: 242-247

4. Rowe JW, Wands JR, Mezey E, Waterbury LA, Wright JR, Tobin J, Andres R (1977) Familial hemochromatosis: Characteristics in the pre-cirrhotic stage in a large kindred. Medicine (Baltimore) 56: 197-211

5. Megyesi K, Samols E, Marks V (1967) Glucose tolerance and diabetes in chronic liver disease. Lancet 2: 1051-1055

6. Creutzfeldt W, Frerichs H, Sickinger K (1970) Liver and diabetes mellitus. In: Popper H, Schaffner F (eds) Progress in liver disease, Vol. III, Grune \& Stratton, New York, pp 371-407

7. Olefsky JM (1982) Insulin resistance in humans. Gastroenterology 83: 1313-1318

8. Blei AT, Robbins DC, Drobny E, Baumann G, Rubenstein AH (1982) Insulin resistance and insulin receptors in hepatic cirrhosis. Gastroenterology 83: 1191-1199

9. Johnston DG, Alberti KGMM, Wright R, Smith-Laing G, Stewart AM, Sherlock S, Faber O, Binder C (1978) C-peptide and insulin in liver disease. Diabetes 27 (Suppl 1): 201-206

10. Bergmeyer HV (1979) Methoden der enzymatischen Analyse. Verlag Chemie, Weinheim

11. Falloona GR, Unger RH (1974) Glucagon. In: Jaffe RB, Behrmann HR (eds) Methods of radioimmunoassay. Academic Press, London, pp $317-330$

12. Starke A, Starke G, Joergens V, Berger M, Zimmermann H (1982) Erhöhte Plasma-Glucagonspiegel bei Adipositas. Dtsch Med Wochenschr 107: 1125-1128

13. Kuzio M, Dryburgh JR, Malloy KM, Brown JC (1974) Radioimmunoassay for gastric inhibitory polypeptide. Gastroenterology 66: 357-364

14. Creutzfeldt W, Ebert R, Willms B, Frerichs H, Brown JC (1978) Gastric inhibitory polypeptide (GIP) and insulin in obesity: increased responses to stimulation and defective feedback control of serum levels. Diabetologia 14: 15-24

15. Pozza G, Ghidoni A (1968) Studies on the diabetic syndrome of idiopathic haemochromatosis. Diabetologia 4: 83-86

16. Stock AE, Powell LW (1973) Carbohydrate intolerance in idiopathic haemochromatosis. Q J Med 168: 733-749

17. Bierens de Haan B, Scherrer JR, Stauffacher W, Pometta D (1973) Studies on the diabetic syndrome in idiopathic haemochromatosis. Eur J Clin Invest 3: 179-187

18. Muller WA, Berger M, Cueppers HJ, Berchtold P, Strohmeyer G, Renold AE, Hostetter JR, Gonvers JJ (1979) Plasma glucagon in diabetes of hemochromatosis: too low or too high? Gut 20: 200-204

19. Passa P, Luyckx AS, Carpentier JL, Lefebvre PJ, Canivet J (1977) Glucagon secretion in diabetic patients with idiopathic haemochromatosis. Diabetologia 13: 509-513

20. Scheuer PJ, Williams R, Muir AR (1962) Hepatic pathology in relatives of patients with idiopathic hemochromatosis. J Pathol Bacteriol 84: $53-64$

Received: 26August 1983

and in revised form: 6 April 1984

Dr. Claus Niederau

University of California

The Medical Service, Room 5 H 22

San Francisco General Hospital (GI-Unit)

San Francisco, CA 94110

USA 